\title{
PERAN KREATIVITAS GENERASI MUDA DALAM INDUSTRI KREATIF TERHADAP KEMAJUAN BANGSA
}

\author{
Yanuar Herlambang, S.Sn., ACA \\ Dosen Program Studi Manajemen Informatika \\ Politeknik LP3I Bandung \\ e-mail: herlambangyanuar@yahoo.com; pandawadesign@yahooo.com
}

\begin{abstract}
Abstrak: Indonesia yang kaya akan sumber daya alam tidak menjadi jaminan menciptakan masyarakatnya sejahtera dan maju, kemerdekaan hanyalah ilusi semata, kemiskinan masih menjadi pekerjaan rumah bangsa ini yang sudah sejak lama belum terselesaikan, buruknya kinerja pemerintah menambah beban yang harus ditanggung generasi muda sebagai generasi penerus, pelestarian budaya kolonialisme kemudian menjadikan bangsa ini sebagai bangsa konsumen, bangsa pengikut.
\end{abstract}

Tidak bisa dipungkiri dengan menjadi negara konsumen kita menjadi 'kaya' akan berbagai pengetahuan, informasi dan produk berteknologi tinggi, ditambah dengan makin meningkatnya jumlah masyarakat kelas menengah yang menjadikan Indonesia sebagai pasar yang besar. Akan tetapi ternyata kita belum dapat menjadi bangsa yang makmur dan mandiri, kita menjadi pasar terbesar ketiga untuk produk sepeda motor akan tetapi kita masih belum dapat memproduksinya sendiri, begitu pula dengan berbagai produk konsumsi lainnya.

Sudah saatnya kita maju dengan landasan pengembangan, bukan lagi hanya pelestari budaya lama yang statis, bukan lagi melihat peluang dari devisa TKI. Kita harus mulai mengandalkan sumber daya manusia yang kreatif, generasi muda yang menjadi solusi yang berorientasi ke masa depan.

Kreativitas jika kita telusuri ternyata memiliki potensi yang besar yang dapat memberikan pengaruh besar pula terhadap berbagai aspek kehidupan yang kita jalani, peran kreativitas para generasi muda sebagai generasi penerus bangsa harus ditingkatkan karena mereka adalah salah satu kekuatan yang dapat mengoptimalkan seluruh potensi bangsa Indonesia.

Kata kunci: kreativitas; generasi muda; budaya; kemajuan bangsa; industri kreatif

\section{Pendahuluan}

Indonesia memiliki perjalanan panjang dalam pembentukan budaya yang kemudian menjadi sebuah kebudayaan yang terlestarikan hingga kini seperti budaya pasif dan budaya 'kolonialisasi', sejak masa kerajaan telah kita ketahui bahwa faktor kekuasaan dan penindasan adalah salah satu budaya para pemimpin masa itu, mereka tidak terlalu mementingkan kesejahteraan atau kemajuan rakyatnya bahkan melakukan pembedaan terhadap derajat di dalam kehidupan sosial, rakyat bawah dikondisikan agar selalu patuh kepada pemimpinnya bagaimanapun kebijakan pemimpin tersebut dan tidak memiliki kesempatan mengembangkan diri. Manusia pada prinsipnya selalu berusaha beradaptasi 
terhadap lingkungannya, sehingga dengan lingkungan dan sistem yang dibuat para pemimpin sejak zaman kerajaan membentuk sebuah kebudayaan pasif kepada para rakyat bawahnya, hal ini membentuk budaya kolonialisasi sehingga para pemimpinnya saling berebut kekuasaan. Kemudian budaya ini terus dilestarikan oleh penjajah asing selama beratus-ratus tahun dengan konsep yang hampir sama, yaitu mengedepankan kepentingan penguasa dan menekan kepentingan rakyat bawah sehingga membentuk budaya follower bukan leader.

Di era kemerdekaan Indonesia saat ini sangat disayangkan jika pemerintah masih menutup mata pada potensi masyarakat khususnya generasi muda, dengan masih melihat bahwa warganya hanya perlu loyal kepada pemimpin dengan faktor kekuasaan sebagai alasannya. Berbagai program pelestarian budaya sering didengungkan baik di daerah maupun perkotaan memiliki berbagai pertimbangan, akan tetapi langkah ini bisa jadi malah secara sadar atau tidak sadar akan terus 'mendidik' warga atau generasi selanjutnya untuk mempertahankan budaya pasif atau 'pasrah' dengan mengesampingkan perlunya pengembangan, sehingga tidak menganggap penting pembangunan kualitas generasi muda yang lebih kreatif, produktif dan maju, program-program tersebut malah bisa jadi sebagai penghambat kreativitas generasi muda. Hal tersebut menyebabkan hanya sebagian kecil dari generasi muda yang memiliki kreativitas, beberapa dari mereka menjadi kreatif hanya karena merasa tertekan akan kondisi sulit yang menerpa kehidupan mereka sehingga tergerak untuk survive, seperti yang diutarakan dalam teori Freud mengenai proses kreatif dari mekanisme pertahanan.

\section{Peran Kreativitas Generasi Muda}

Generasi muda Indonesia saat ini sebagai penerus bangsa di masa depan harus memiliki 'senjata' yang dapat 'memerdekakan' bangsa ini sehingga dapat mandiri dan sejahtera, 'senjata' yang dapat memunculkan banyak inovasi yang berdaya saing dan sesuai dengan kebutuhan masyarakat. Pada dasarnya manusia memiliki kemampuan akal secara natural dalam berhadapan dengan permasalahan, manusia akan selalu mengembangkan solusi terhadap berbagai permasalahan yang ada, dengan begitulah sebuah peradaban ada dan berkembang, dalam proses inilah kreativitas dibutuhkan.

\subsection{Pengertian Kreativitas}

Kreativitas menurut kamus besar Bahasa Indonesia (Trisno,1994) berasal dari kata dasar kreatif, yaitu memiliki kemampuan untuk menciptakan sesuatu. Menurut Oxford English Dictionary (Oxford, 2013), Creativity adalah "the use of imagination or original ideas to create something; inventiveness:" dimana pengertian inventive adalah "having the ability to create or design new things or to think originally".

Menurut NACCCE (National Advisory Committee on Creative and Cultural Education) dalam Craft (2005), kreativitas adalah aktivitas imaginatif yang menghasilkan hasil yang baru dan bernilai. Dalam sumber yang sama Feldman mendefinisikan kreativitas adalah "the achievement of something remarkable and new, something which transforms and changes a field of endeavor in a 
significant way ... the kinds of things that people do that change the world." .

Menurut Guilford dalam Munandar (2009) menyatakan kreativitas merupakan kemampuan berpikir divergen atau pemikiran yang memiliki beragam pilihan solusi yang sama benarnya terhadap sebuah persoalan.

Menurut Csikszentmihalyi dalam Clegg (2008) menyatakan kreativitas sebagai suatu tindakan, ide, atau produk yang mengganti sesuatu yang lama menjadi sesuatu yang baru. Menurut Munandar (1985), kreativitas adalah kemampuan untuk membuat kombinasi baru, berdasarkan data, informasi atau unsur-unsur yang ada, hasil yang diciptakan tidak selalu hal-hal yang baru, tetapi juga dapat berupa gabungan (kombinasi) dari hal-hal yang sudah ada sebelumnya.

Drevdahl mengungkapkan bahwa kreativitas merupakan kemampuan untuk mencipta karangan, hasil, atau ide-ide yang sebelumnya tidak dikenal oleh pencipta. Kemampuan ini merupakan aktivitas imajinatif atau berpikir sintesis, yang hasilnya merupakan pembentukan kombinasi dan informasi yang diperoleh dari pengalaman-pengalaman sebelumnya menjadi hal yang baru, berarti, dan bermanfaat.

Kreativitas menurut Hurlock mengungkapkan bahwa suatu proses yang menghasilkan sesuatu yang baru, apakah suatu gagasan atas suatu objek dalam suatu bentuk atau susunan yang baru, proses tersebut berupa munculnya suatu produk baru yang muncul dari keunikan individu dan juga dari beberapa pengaruh dari pihak lain.

Secara umum dapat ditarik kesimpulan bahwa kreativitas adalah kemampuan imajinasi atau berpikir kreatif seseorang secara individu yang dapat juga dipengaruhi oleh lingkungannya dalam penciptaan sebuah produk atau sesuatu yang memiliki daya-guna atau proses desain terhadap output yang memiliki kebaruan.

\subsection{Teori Kreativitas}

Secara umum teori kreativitas berlandaskan beberapa pendekatan multidisiplin lainnya seperti:

1. Teori psikoanalitik. Proses ketidaksadaran melandasi kreativitas, kreativitas merupakan manifestasi dari kondisi psikopatologis. Pribadi yang kreatif dipandang sebagai seorang yang pernah mengalami traumatis, yang dapat memunculkan gagasan-gagasan yang disadari dan tidak disadari, serta bercampur menjadi satu antara pemecahan inovatif dan trauma.

Beberapa pakar yang mendukung teori ini adalah sebagai berikut (dalam Basuki, 2010):

a. Teori Freud. Freud menjelaskan proses kreatif dari mekanisme pertahanan (defense mechanism). Freud percaya bahwa meskipun kebanyakan mekanisme pertahanan menghambat tindakan kreatif, 
mekanisme sublimasi justru merupakan penyebab utama kreativitas.

b. Teori Ernst Kris. Orang yang kreatif menurut teori ini adalah mereka yang paling mampu memanggil pikiran tidak sadar. Ernst Kris menekankan bahwa mekanisme pertahanan regresi muncul seiring memunculkan tindakan kreatif, melakukan regresi demi bertahannya ego (Regression in The Survive of The Ego).

c. Teori Carl Jung. Alam ketidaksadaran (ketidaksadaran kolektif) memainkan peranan yang amat penting dalam pemunculan kreativitas tingkat tinggi. Dari ketidaksadaran kolektif ini timbil penemuan, teori, seni dan karya-karya baru lainnya.

2. Teori Asosiasi. Kreativitas sebagai hasil dari proses asosiasi dan kombinasi antara elemen-elemen yang telah ada, sehingga menghasilkan sesuatu yang baru.

3. Teori Gestalt. Kreativitas sebagai manifestasi dari proses tilikan individu terhadap lingkungannya secara holistik.

4. Teori eksistensial. Kreativitas merupakan proses untuk melahirkan sesuatu yang baru melalui perjumpaan antara manusia dengan manusia, dan antara manusia dengan alam. Menurut May (1980) setiap perilaku kreatif selalu didahului oleh 'perjumpaan' yang intensif dan penuh kesadaran antara manusia dengan dunia sekitarnya.

5. Teori Intepersonal. Pencipta (kreator) sebagai inovator dan orang di sekelilingnya sebagai pihak yang mengakui hasil kreativitas dalam konteks lingkungan sosial. Teori ini menekankan pentingnya nilai dan makna dari suatu karya kreatif. Nilai mengimplikasikan adanya pengakuan sosial.

6. Teori Sifat atau Ciri. Memberikan tempat khusus kepada usaha untuk mengidentifikasi ciri-ciri atau karakteristik-karakteristik utama kreativitas. Csikszentmihalyi mengelompokkan kreativitas kedalam 2 kategori little c dan big c, contoh kreativitas keseharian yang merupakan solusi terhadap kebutuhan dasar masuk kedalam kategori little $\mathrm{c}$.

7. Teori Humanistik Maslow. Abraham Maslow (dalam Basuki, 2010) berpendapat bahwa manusia mempunyai naluri-naluri dasar yang menjadi nyata sebagai kebutuhan, kebutuhan tersebut adalah kebutuhan fisik atau biologis, kebutuhan akan rasa aman, kebutuhan akan rasa dimiliki dan cinta, kebutuhan akan penghargaan dan harga diri, kebutuhan aktualisasi atau perwujudan diri, Kebutuhan estetik. Semua Kebutuhan tersebut memiliki hierarkis. Keempat Kebutuhan pertama disebut kebutuhan "deficiency". Kedua Kebutuhan berikutnya (aktualisasi diri dan estetik atau transendentasi) disebut kebutuhan "being". Proses perwujudan diri berkait erat dengan kreativitas. Bila bebas dari neurosis, orang yang mewujudkan dirinya mampu memusatkan dirinya pada yang hakiki.

8. Teori Pendorong. Kreativitas dapat terwujud dengan adanya dorongan dari diri individu (intrinsic) dan lingkungan (extrinsic). Dalam perwujudannya memerlukan dorongan internal maupun eksternal dari lingkungan.

Munandar (2002) menyatakan, pada pribadi yang kreatif, jika memiliki kondisi pribadi dan lingkungan yang menunjang seperti lingkungan yang memberikan kesempatan kepada individu untuk menyibukkan diri secara 
kreatif, maka akan dapat diprediksikan bahwa produk kreatifitasnya akan muncul.

9. Teori Proses Kreatif Wallas. Teori ini mengatakan bahwa proses kreatif meliputi empat tahap yaitu: (1) persiapan, (2) inkubasi, (3) iluminasi, (4) verifikasi. Teori Wallas terdapat dalam buku The art of Thought.

\subsection{Faktor-Faktor Yang Mempengaruhi Kreativitas}

Kreativitas dinyatakan dalam bentuk produk-produk kreatif baik berupa benda maupun gagasan (creative ideas), dalam diri seseorang terdapat faktor-faktor yang dapat menunjang atau menghambat kreativitas. Aktualisasi kreativitas merupakan hasil dari proses interaksi antara faktor-faktor psikologis (internal) dengan lingkungan (eksternal). Faktor yang mempengaruhi kreativitas: faktor internal: jenis kelamin, usia, urutan kelahiran, dan inteligensi. Faktor eksternal meliputi waktu, kesempatan untuk memperoleh pengetahuan, status sosial ekonomi, sarana, dan lingkungan yang merangsang. Rhodes mengatakan bahwa ada 4 aspek dasar yang mempengaruhi kreativitas yang saling berkaitan yaitu 4P, Person-Process-Place-Product.

Kreativitas memerlukan lingkungan yang baik untuk berkembang, perkembangan kota Bandung sebagai kota yang dikenal kreatif merupakan contoh yang baik terhadap pentingnya lingkungan yang kondusif, budaya masyarakat yang dapat menyerap perubahan global dengan baik, masyarakat yang dapat menerima dengan baik para pendatang, integrasi yang baik antara masyarakat dengan kalangan akademisi, dan besarnya apresiasi masyarakat terhadap karya kreatif.

\subsection{Proses Berpikir Kreatif}

Proses berpikir kreativitas terdiri dari konvergen dan divergen, oleh Guilford (1967) dikatakan sebagai bentuk pemikiran terbuka, yang menjajagi macammacam kemungkinan jawaban terhadap suatu persoalan/masalah. Ciri-ciri Creative Person menurutnya adalah: Fluency; Sensitivity; Flexibility; Originality; Redefinition; Elaboration; Tolerance of ambiguity; Commitment; Risk taking. Digambarkan dalam sebuah model struktur intelek dalam bentuk kubus yang dikelompokkan ke dalam tiga matra yaitu:

1. Matra operasi (proses), yang memuat lima proses berpikir yaitu: kognisi, ingatan, berpikir divergen, berpikir konvergen, dan evaluasi.

2. Matra konten (materi), menunjukkan bermacam-macam materi yang digunakan meliputi empat materi yaitu: figural, simbolik, sematik, dan behavioral.

3. Matra produk, menunjukkan hasil dan proses tertentu yang diterapkan dalam materi tertentu mencakup enam bentuk yaitu: unit, kelas, hubungan, sistem, tranformasi dan implikasi.

Tahapan proses kreatif menurut Torrance adalah sebagai berikut:

1) Sensing difficulties, problems, gaps in information, missing elements, something asked.

2) Making guesses, formulating hypotheses about these deficiencies. 
3) Evaluating, testing these guesses and hypotheses.

4) Possibly revising, retesting them.

5) Communicating the results.

Dalam terjemahan bebasnya proses kreatif berawal dari kemampuan melihat masalah, kesulitan, dan berbagai pertanyaan, kemudian membuat formulasi masalah dan hipotesis, dilanjutkan dengan melakukan evaluasi dan pengujian hipotesis, kemudian membuat daftar alternatif solusi dengan pengujiannya, dan terakhir mendistribusikan hasil yang didapat.

\section{Industri Ekonomi Kreatif}

Definisi industri kreatif menurut Departemen Perdagangan Republik Indonesia tahun 2007 adalah Industri yang berasal dari pemanfaatan kreativitas, keterampilan serta bakat individu untuk menciptakan kesejahteraan serta lapangan pekerjaan melalui penciptaan dan pemanfaatan daya kreasi dan daya cipta individu tersebut. Dalam buku Rencana Pengembangan Ekonomi Kreatif Indonesia 2009 dijelaskan bahwa salah satu faktor yang memiliki peran signifikan dalam ekonomi kreatif adalah sumber daya manusia yang kreatif.

Department of Culture, Media, and Sport (DCMS) mendefinisikan Industri kreatif sebagai berikut: "Creative Industries as those industries which have their origin in individual creativity, skill \& talent, and which have a potential for wealth and job creation through the generation and exploitation of intellectual property and content (Creative Industries Task Force, 1998). Dalam terjemahan bebas dapat dikatakan bahwa industri kreatif adalah industri yang memiliki originalitas tersendiri dalam hal kreativitas individual, bakat dan kemampuan, yang mana memiliki potensi ekonomi dan penciptaan lapangan kerja melalui eksplorasi konten kreatif dan hak cipta dari produk-produk kreatif yang dikembangkan oleh sumber daya manusia yang kreatif.

Konsep ekonomi kreatif ini sebelumnya sudah diperkenalkan Schumpeter sejak tahun 1911, tersirat dalam risalah klasiknya Theorie der wirtschaftlichen Entwicklungen (Teori Pembangunan Ekonomi), Schumpeter mengusulkan sebuah teori tentang "creative destruction". Teori ini menyatakan bahwa perusahaan baru dengan spirit kewirausahaan muncul dan menggantikan perusahaan lama yang kurang inovatif. Fenomena ini selanjutnya mengarahkan dinamika kehidupan dunia usaha ke tingkat pertumbuhan ekonomi yang lebih tinggi.

Industri kreatif sebagai industri yang sedang berkembang saat ini adalah, pemerintah telah mengidentifikasi lingkup industri kreatif mencakup 14 subsektor:

1. Periklanan (advertising)

2. Arsitektur

3. Pasar Barang Seni

4. Kerajinan (craft)

5. Desain

6. Fesyen (fashion)

7. Video, Film dan Fotografi

8. Permainan Interaktif (game) 


\section{Musik}

10. Seni Pertunjukan (showbiz)

11. Penerbitan dan Percetakan

12. Layanan Komputer dan Piranti Lunak (software)

13. Televisi \& Radio (broadcasting)

14. Riset dan Pengembangan (R\&D).

Dengan kondisi pasar yang terbentuk saat ini ekonomi kreatif yang merupakan pengembangan konsep yang berlandaskan sumber aset kreatif yang dapat berfungsi secara signifikan meningkatkan pertumbuhan potensi ekonomi. Menurut Howkins, bahwa ekonomi baru telah tumbuh di seputar industri kreatif yang dikendalikan oleh hukum kekayaan intelektual seperti paten, hak cipta, merek, royalti dan desain. Hal ini telah dibuktikan di Indonesia bahwa, PDB industri kreatif meningkat dari tahun ke tahun, PDB industri kreatif saat ini didominasi oleh kelompok fesyen, kerajinan, periklanan, desain, animasi, film, video dan fotografi, musik, serta permainan interaktif.

Industri kreatif ini pula dapat meningkatkan laju pertambahan wirausaha, dikarenakan basisnya adalah kreatifitas sehingga para start-up yang hanya memiliki modal terbatas pun masih dapat menjalankan ekonomi basis ini dengan baik. Dari dimensi subjek perilaku individual, kewirausahaan pada hakekatnya adalah sifat, ciri dan watak seseorang yang memiliki kemauan dalam mewujudkan gagasan inovatif ke dalam dunia nyata secara kreatif. Untuk memenangkan persaingan, maka seorang wirausahawan harus memiliki daya kreativitas yang tinggi, daya kreativitas tersebut sudah seharusnya dilandasi oleh cara berpikir yang maju, penuh dengan gagasan-gagasan baru yang berbeda dengan produkproduk yang telah beredar dan dikenal saat ini.

Para generasi muda yang memiliki potensi mengembangkan ekonomi kreatif ini harus dapat selalu mengembangkan diri dengan berbagai inovasi terhadap produkproduknya, karena dengan bertambahnya guna atau manfaat pada sebuah produk, maka meningkat pula daya jual produk tersebut di pasar, karena adanya peningkatan nilai ekonomis bagi produk tersebut bagi konsumen. OECD (1998) mendefinisikan wirausahawan sebagai berikut: "Wirausahawan adalah agen perubahan dan pertumbuhan di dalam sebuah pasar suatu sistem perekonomian yang berfungsi mempercepat penciptaan, penyebaran dan penerapan gagasangagasan inovatif, sehingga entrepreneurs not only seek out and identify potentially profitable economics opportunities but also willing to take risks to see if their hunches are right".

\subsection{Pengembangan Teknologi}

Perkembangan teknologi di Indonesia sudah sangat maju, terbukti dengan cepatnya diagram kepemilikan produk-produk berteknologi tinggi, akan tetapi kita perlu melihat dulu seperti apa posisi kita terhadap perkembangan teknologi tersebut, ternyata masyarakat kita ataupun generasi baru kita hanya menjadi konsumen dari produk-produk bangsa lain tanpa dapat bersaing dalam menciptakan teknologi sendiri yang dapat menguntungkan Indonesia secara keseluruhan, lagi-lagi kita terjebak dalam penjajahan bentuk lain dan tidak 
dapat mengoptimalkan berbagai potensi yang sebenarnya ada di alam Indonesia maupun dalam sumber daya manusianya.

Kini adalah zaman dimana globalisasi menyentuh semua lini kehidupan manusia, informasi menyebar secara cepat, geografis bukan lagi halangan untuk berkomunikasi, dan berbagai perkembangan lainnya yang menjadikan persaingan ekonomi mengarah kepada users oriented, kekuatan interaksi, bukan lagi hanya sebagai pemenuhan kebutuhan pokok, seperti pada teori humanistik Maslow bahwa saat ini manusia sudah banyak yang telah mencapai level aktualisasi diri, sehingga menuntut segala hal yang berkaitan dengan aktivitas mereka memiliki value yang lebih, keunikan, mencerminkan ide segar, kebaruan, diferensiasi berupa gaya hidup dan sebagainya.

Dengan perkembangan teknologi informasi yang men-global saat ini harusnya dapat digunakan secara optimal oleh generasi muda untuk dapat mengupgrade kualitasnya sebagai kekuatan untuk kepemimpinan masa akan datang. Perkembangan teknologi manufaktur pun berkembang dengan pesat saat ini, dengan begitu generasi muda dapat mencurahkan secara lebih luas kreatifitasnya dengan menggunakan produk-produk tersebut, para generasi muda selaku pelaku kreatif tidak lagi terhambat dengan masalah penerapan ilmu dan kreatifitas yang dimiliki, yang selama ini sulit diaplikasikan karena keterbatasan kepemilikan mesin atau alat manufaktur yang biasanya dimiliki oleh perusahaan pabrikasi besar atau pabrikasi luar negeri, banyak pihak sudah mulai menyadari akan kekuatan baru yaitu Industri berbasis kreatif yang telah menjadi industri 'seksi' dewasa ini.

Dengan segala perkembangan teknologi yang ada, saat ini di berbagai belahan dunia lain sudah mulai berkembang gerakan kreativitas baru dengan nafas Do It Your-self, gerakan ini perlu disikapi dengan baik karena akan dapat menggerakkan para generasi muda Indonesia untuk berpikir dengan cara berpikir kreatif sebagaimana yang dilakukan oleh para desainer.

Dengan gerakan tersebut sesuai dengan teori interpersonal maka para generasi muda disuguhi lingkungan yang lebih dinamis, lebih respect terhadap kreativitas, hal ini dapat menjadi stimulan untuk lebih peka terhadap segala sesuatu yang ada di sekelilingnya seperti kebutuhan yang tidak tersentuh, mencari solusi akan masalah yang praktis, kemampuan bereksperimen untuk mengembangkan teknik produksi dan teknologi yang baru, dan mampu mengembangkan budaya yang lama dan mengembangkannya dengan nafas kebaruan.

\subsection{Budaya Baru Generasi Muda Dengan Semangat Budaya Desainer (Kreatif, Solusi, Mandiri, Optimis, Peka, Kritis, Empati)}

Pergerakan pemuda sebagai generasi penerus kepemimpinan Indonesia masa akan datang, kini harus dapat melawan dan merubah budaya pasif dan 'kolonialisasi' yang selama ini 'terlestarikan' dengan kuat. Pelestarian budaya lama bisa jadi merupakan kedok politisasi dari pelemahan semangat generasi baru akan perkembangan dan kemajuan. 
Jika kita ingin generasi muda kita menjadi generasi yang unggul di semua bidang dan dapat memajukan bangsa ini baik secara kualitas hidup, pemikiran, maupun pemerataan pembangunan maka sudah selayaknya kita khususnya sebagai desainer turut berjuang agar generasi muda kita menjadi generasi yang kritis dan solutif bagi semua lini kehidupan berbangsa dan bernegara. Kita dapat ikut membangun mental generasi muda dengan mengedepankan cara berfikir kreatif, cara berfikir dengan nafas pengembangan, berfikir maju. Kita dapat membuat lingkungan yang baik untuk mereka beradaptasi, lingkungan yang inspiratif, lingkungan dengan atmosfer persaingan kreatifitas dan penciptaan teknologi yang praktis.

Dalam pendekatan design thinking dikatakan bahwa pemikiran kreatif dapat menjadi proses solusi yang rasional terhadap sebuah masalah dan memecahkannya secara praktis atau aplikatif melalui pendekatan ini kita dapat menemukan berbagai solusi atas sebuah permasalahan yang sebelumnya kita amati. Sebagai desainer kita harus memiliki unsur empati dalam melihat permasalahan dan menawarkan solusi dan kemudian mengkombinasikannya dengan kreativitas secara rasional yang dapat diaplikasikan, walaupun solusi tersebut belum tentu dipandang sebagai solusi yang populer.

Dapat dibayangkan jika kebanyakan generasi muda memiliki cara berpikir seperti desainer, seperti diantaranya kreatif, pemberi solusi, mandiri, optimis, peka, kritis, empati, maka dapat dipastikan kita memiliki potensi pemimpin yang visioner yang besar dan juga memiliki potensi pendukung yang kuat pula. Maka sangatlah perlu saat ini untuk memupukkan budaya desainer ini pada generasi muda agar mampu mendorong munculnya generasi kepemimpinan baru yang dapat merombak budaya lama yang bernafas kepasifan dan penjajahan menjadi budaya baru yang pro kemajuan secara menyeluruh, baik secara kualitas maupun kuantitas. Karena budaya yang akan dijalankan oleh generasi yang akan datang adalah budaya yang ditanamkan oleh generasi sebelumnya.

\subsection{Peran Pemerintah}

Kini adalah saat yang tepat bagi para generasi muda yang kreatif dapat dengan cepat tumbuh sebagai pemberi kontribusi secara ekonomi kepada bangsa, karena saat ini pemerintah pun sudah mulai melirik potensi industri kreatif sebagai cara untuk meningkatkan daya saing produk nasional dalam menghadapi pasar global. Pemerintah melalui Departemen Perdagangan yang bekerja sama dengan Departemen Perindustrian dan Kementerian Koperasi dan Usaha Kecil Menengah (UKM) serta didukung oleh KADIN kemudian membentuk tim Indonesia Design Power 20062010 yang bertujuan untuk menempatkan produk Indonesia menjadi produk yang dapat diterima di pasar internasional namun tetap memiliki karakter nasional.

Untuk mengakomodasi perkembangan yang ada bahwa kontribusi ekonomi kreatif terhadap negara besar, maka pemerintah melakukan studi yang lebih intensif dan mengembangkan cetak biru pengembangan ekonomi kreatif. 
Upaya mendukung visi Indonesia menjadi negara yang maju melalui ekonomi kreatif telah dicanangkan hingga tahun 2025 yang terbagi dalam 2 tahapan. Pada tahapan pertama sasaran pencapaian hingga tahun 2015 adalah memperkuat fondasi dan pilar ekonomi kreatif sedangkan pada tahap kedua merupakan tahap akselerasi hingga tahun 2025.

Pemerintah saat ini sudah mulai mendekati generasi muda dengan mengadakan berbagai sosialisasi dan pembinaan maupun pengembangan sumber daya manusia kreatif baik di lingkungan akademisi seperti sekolahsekolah, perguruan tinggi, maupun di lingkungan non-formal. Di lingkungan akademisi saat ini sudah mulai diterapkan berbagai kurikulum yang dapat men-trigger mahasiswa dan juga dengan berbagai pembekalan dan program yang dapat menstimulus kreativitas dan produktivitas, seperti Kurikulum entrepreneurship, Program kewirausahaan kampus seperti Rumah Entrepreneur, program Penelitian IBK (IPTEK Bagi Kewirausahaan), Program Hibah Kompetitif, Penelitian Unggulan Strategis Nasional, hingga programprogram dukungan dari pihak swasta yang berupa bantuan permodalan usaha bagi wirausahawan baru, seminar, pelatihan, kuliah tamu dan lain sebagainya.

\section{Kesimpulan Dan Saran}

Kreativitas tidak hanya berbicara mengenai daya imajinasi saja akan tetapi kreativitas harus bersifat membumi dan praktis, kreativitas harus dapat menjadi produktif. Generasi muda yang memiliki kreativitas tinggi merupakan suatu kekuatan besar yang dapat membangun dan memajukan bangsa ini, dimana dalam proses kreativitas terdapat karakter yang kaya akan pemikiran kreatif, solusi, mandiri, optimis, peka, kritis hingga empati.

Kreativitas perlu mendapatkan lingkungan yang kondusif untuk dapat menyusup dengan cepat dan meluas kedalam karakter generasi muda, pemerintah perlu mendukung dan membina agar dapat menjadi kekuatan besar bagi bangsa ini, peran para desainer maupun developer diharapkan dapat membangun atmosfer yang lebih baik lagi kepada arah pengembangan dan kemajuan, berjalan menuju konsep leader bukan lagi follower, menuju produktivitas bukan hanya sekedar konsumeris.

\section{Daftar Pustaka}

[1] Alisyabbana, ST. 1983. Kreativitas. Jakarta: Dian Rakyat.

[2] Amabiie,T.M. 1983. The Social Psychology of Creativity. New York: Springer- Verlag.

[3] Ambrose, Paul Harris. 2010. Design Thinking. AVA Publishing SA.

[4] Basuki, Heru. 2010. Pengembangan Kreativitas. Artikel.

[5] Clegg, P. 2008. Creativity and Critical Thinking in The Globalised University. Innovations in Education and Teaching International Vol. 45, No. 3. Taylor \& Francis.

[6] Craft, A. (Ed). 2005. Creativity in Schools Tensions and Dilemmas. New York: Routledge.

[7] Departemen Perdagangan RI. 2008. Pengembangan Ekonomi Kreatif Indonesia 2025. 
[8] Guilford,J.P. 1965. Factor That Aid and Hinder Creativity. Teachers Record.

[9] Mackler,B \& Shontz,F.C. 1975. Creativity: Theoritical and Methodological Considerations. The Phsychological Record.

[10] Maslow, Abraham H. 1994. Motivasi dan Kepribadian I, Teori Motivasi dengan Pendekatan hierarki Kebutuhan Manusia. Bandung: PT. Pustaka Binaman Pressindo.

[11] May,R. 1980. The Courage to Create. Boston: Norton\&Co.

[12] Munandar, Utami. 2002. Kreativitas dan Keberbakatan Strategi Mewujudkan Potensi Kreatif dan Bakat. Jakarta: Rineka Cipta.

[13] . 2009. Pengembangan Kreativitas Anak Berbakat. Jakarta: Rineka Cipta.

[14] Oxford. 2013. Online English Dictionaries. Oxford University Press. Diambil dari : http://oxforddictionaries.com/definition/english/

[15] Roeger,A. 1982. Psycologycal Approach to Creativity in Science. Dalam A.Rothen Berg \& ER.Hausman(Eds.),Thc Creativity Question. Drham: Duke University.

[16] Stein.M.L. 1967. Creativity and Culture. Dalam R.L Moerey \& T.A.Razik Exploration in Creativity. New York: Harper.

[17] Supriadi, Dedi. 1994. Kreativitas, Kebudayaan dan Perkembangan iptek. Bandung: Alfabeta .

[18] Trisno Yuwono. 1994. Kamus Lengkap Bahasa Indonesia. Surabaya: Arkola. 